\title{
Legal bases and economic conditions of applying renewable energy resources in construction industry
}

\author{
Marek Ramczyk ${ }^{*}$ \\ University of Science and Technology in Bydgoszcz, Faculty of Civil and Environmental Engineering \\ and Architecture, Al. prof. S. Kaliskiego 7, 85-796 Bydgoszcz, Poland
}

\begin{abstract}
European Union, including Poland, has not yet introduced full and complex legal regulations exclusively regarding energy-efficient construction. However, legal regulations do define the possibility of using renewable energy resources in the construction industry. In this article you can find a detailed overview of legal regulations concerning the bases of using renewable energy resources in the construction industry. They involve investors, designers and contractors. The article also indicates economic instruments supporting the energy-efficient construction in Poland.
\end{abstract}

\section{Introduction}

The term 'energy-efficient construction' was entered in Western Europe in the 1970s during the first energy (oil) crisis. The fuel crisis forced the necessity to save energy and to start using renewable energy sources in a larger scale in the construction industry. As the result, the concept of building energy efficient houses appeared in the 1980s. In 1988, German physicist and construction engineer Wolfgang Feist and Bo Adamson, at Lund University in Sweden, invented the standards for a passive house that can function almost completely without heating. A building, constructed according to these standards, would have the annual heat demand of less than $15 \mathrm{kWh} / \mathrm{m}^{2}$ (equivalent to 1.51 of heating oil or $1.7 \mathrm{~m}^{3}$ of natural gas or $2.3 \mathrm{~kg}$ of hard coal) and the annual primary energy demand, including hot water and electricity, would be below $120 \mathrm{kWh} / \mathrm{m}^{2}$. The world's first experimental passive house was built in 1991 in Darmstadt (Germany). It was designed and built by the team of architects, H. Bott, K. Ridder and H. Westermeyer, on the basis of standards developed by W. Feist i B. Adamson and funded by the Ministerium für Wirtschaft und Technik in Hesse. The pioneer passive house in Darmstadt is a terraced house with four apartments, with an area of $156 \mathrm{~m}^{2}$ each. It was build of modern building materials and with the use of innovative architectural solutions. It is located in the way that allows optimum use of sunlight. The above causes that the annual unit energy demand for heating and ventilation (EUco) of this building is $10 \mathrm{kWh} / \mathrm{m}^{2}$.

\footnotetext{
* Corresponding author: marek.ramczyk@utp.edu.pl
} 
The high costs of constructing the first passive building in the history temporarily stopped the development of energy-saving construction technologies. However, on the initiative of W. Feist, the Passive House Institute (Passivhaus Institut) was established in Darmstadt in 1996 and it still implements the idea of passive houses and the optimisation of components for their construction to this day. The main concept of building a passive house was created during construction of the building in Darmstadt. The idea was restored in 1998 through financial support by the European Union in the form of CEPHEUS project (within the THERMIE program of the European Commission). The project included construction of 14 buildings (covering 258 residential units) in the passive house standard in Germany, Austria, Switzerland, Sweden and France. As the result, the number of energy-efficient and passive buildings, both single-family and multi-family houses as well as public buildings, has increased in Western Europe over several years.

Since 1980s, the idea of energy-efficient construction has been spreading around the world. Most of passive constructions are built in German-speaking and Scandinavian countries. According to data from 2014, there are around 40,000 passive buildings in the world and almost half of them are in Germany.

The first passive house in Poland as well as in Central and Eastern Europe, certified by the Passive House Institute (Passivhaus Institut) in Darmstadt, was built in Smolec near Wrocław. The annual unit energy demand for heating and ventilation (EUco) of the building in the standard heating season is $15 \mathrm{kWh} / \mathrm{m}^{2}$. The same house built in accordance with currently applicable standards in Poland would consume $123 \mathrm{kWh} / \mathrm{m}^{2}$ per year, i.e. over 8 times more [3]. The only Polish unit authorised to certify passive buildings is the Polish Institute of Passive Construction and Renewable Energy in the name of Günter Schlagowski in Gdańsk.

Along with the development of energy-efficient construction (including house construction in the passive standard), there has also been rapid development of construction companies specialising in energy-efficient construction technology, companies producing energy-efficient building components (e.g. windows and window frames, doors and door frames) and companies involved in the production of modern building materials, devices and installations necessary to obtain the standard of an energy-efficient (passive) building. Further development of energy-saving construction depends on the implementation scale of the concept of self-sufficient (autonomous) building concept equipped with renewable energy installations.

The primary criterion for energy efficiency is to obtain an appropriate indicator of the annual unit energy demand for heating and ventilation (EUco), calculated in accordance with the Regulation [1]. By the standards of the National Fund for Environmental Protection and Water Management, it is assumed that an 'energyefficient building (house)' is a building (house) for which the annual unit energy demand for heating and ventilation (EUco) is $\leq 40 \mathrm{kWh} / \mathrm{m}^{2}$, while a 'passive house (house)' is characterised by the annual unit energy demand for heating and ventilation (EUco) $\leq 15$ $\mathrm{kWh} / \mathrm{m}^{2}$. For comparison, the energy-efficiency indicator at the EUco level for standard buildings (implemented in traditional technology) is $90-120 \mathrm{kWh} / \mathrm{m}^{2}$ [2].

The definition of nearly zero-energy building was introduced in EU law in 2010. 'Nearly zero-energy building' means a building that has a very high energy performance, as determined in accordance with Annex I of the Directive on energy, while the nearly zero or very low amount of energy required should be covered to a very significant extent by energy from renewable sources, including energy from renewable sources produced onsite or nearby. In Poland, this standard will apply from 1 January 2021 to all buildings, and for buildings occupied and owned by a public authorities from 1 January 2019. 


\section{Legal regulations on the use of renewable energy sources in the construction industry}

Each adopted directive of the European Union must be implemented in Polish law. The European Union has not yet introduced full and comprehensive regulations relating exclusively to energy efficient construction. The adopted EU directives regulate wider issues (especially energy efficiency) and only partly relate to the construction of energy efficient and passive facilities. Hence, the legislation in this area in the European Union, including Poland, is not codified in one leading legal act (legal regulations are divided into various legal acts). However, these legal provisions regulate the possibility of using renewable energy sources in the construction industry. They apply to investors, designers and contractors.

\section{Legal regulations in the European Union legislation}

The following legal acts (presented chronologically) regulate the possibility of using renewable energy sources in the construction industry in the European Union [3, 4]:

- Directive 2006/32/EC of the European Parliament and of the Council of 5 April 2006 on energy end-use efficiency and energy services and repealing Council Directive 93/76/EEC (Official Journal of the European Union No L 114 of 27 April 2006),

- Directive 2009/28/EC of the European Parliament and of the Council of 23 April 2009 on the promotion of the use of energy from renewable sources and amending and subsequently repealing Directives 2001/77/EC and 2003/30/EC (Official Journal of the European Union No L 140 of 05 June 2009),

- Directive 2010/31/EU of the European Parliament and of the Council of 19 May 2010 on the energy performance of buildings (recast) (Official Journal of the European Union No L 153 of 18 June 2010),

- Directive 2012/27/EU of the European Parliament and of the Council of 25 October 2012 on energy efficiency, amending Directives 2009/125/EC and 2010/30/EU and repealing Directives 2004/8/EC and 2006/32/EC (Official Journal of the European Union No L 315 of 14 October 2012).

Directive 2006/32/EC of the European Parliament and of the Council of 5 April 2006 on energy end-use efficiency and energy services and repealing Council Directive 93/76/EEC (Official Journal of the European Union No L 114 of 27 April 2006) was adopted in 2006 in order to improve energy end-use efficiency, energy demand management and to support production from renewable energy sources. This legal act obliges EU Member States to implement energy saving methods and use energy-saving devices to achieve the $9 \%$ energy savings target. It should be noted that the Directive highlights the support for the production of energy from renewable sources, which may have a positive impact on the development of energy-efficient construction industry.

Directive 2009/28/EC of the European Parliament and of the Council of 23 April 2009 on the promotion of the use of energy from renewable sources (Official Journal of the European Union No L 140 of 05 June 2009) creates opportunities for the development of energy-efficient construction through the implementation of renewable energy installations in the construction sector. These possibilities are strongly supported by the stringent requirements of Directive 2010/31/EU of the European Parliament and of the Council of 19 May 2010 on the energy performance of buildings (recast) (Official Journal of the European Union No L 153 of 18 June 2010), which refer to energy efficiency in the construction sector. According to the regulations of the Directive, all new buildings will have to meet higher energy standards in a few years. The European Union 
requires Member States to: 1) by 31 December 2020, all new buildings are nearly zeroenergy buildings, and 2) after 31 December 2018, new buildings occupied and owned by public authorities are nearly zero-energy buildings. Moreover, Member States are obliged to draw up national plans in order to increase the number of nearly zero-energy buildings. However, these plans may include targets differentiated according to the category of building. Member States, taking as an example the public sector, have to develop policies and take action to develop assumptions in order to stimulate the transformation of buildings that are refurbished into nearly zero-energy buildings. The Directive also includes the regulation that the European Commission, by 31 December 2012 and every three years thereafter, is obliged to publish a report on the progress of Member States in increasing the number of nearly zero-energy buildings. Subsequently, the European Commission, based on that report, is obliged to develop an action plan and, if necessary, propose measures to increase the number of those buildings and encourage best practices as regards the cost-effective transformation of existing buildings into nearly zero-energy buildings.

Directive 2012/27/EU of the European Parliament and of the Council of 25 October 2012 on energy efficiency, amending Directives 2009/125/EC and 2010/30/EU and repealing Directives 2004/8/EC and 2006/32/EC (Official Journal of the European Union No L 315 of 14 October 2012) was adopted in 2012 and it imposes an obligation on Member States to reduce energy consumption by $20 \%$ until 2020 . To meet this requirement, Member States should distribute the use of smart metering system of energy consumption, installations of renewable energy sources and energy efficient technologies. The International Energy Agency (IEA) notices the largest growth potential of energy efficiency in buildings and in energy production.

\section{Legal regulations in Polish legislation}

The following legal acts regulate the use of renewable energy sources in the construction industry in Poland as at 31 August 2017 [5]:

- Act on the energy performance of buildings of 29 August 2014 (Journal of Laws of 2014, item 1200 as amended),

- Regulation of the Minister of Infrastructure and Development on the methodology for determining the energy performance of a building or part of a building and energy performance certificates of 27 February 2015 (Journal of Laws of 2015, item 376),

- Act on energy efficiency of 20 May 2016 (Journal of Laws of 2016, item 831),

- Regulation of the Minister of Economy on the detailed scope and method of preparation of the energy efficiency audit, the model of the energy efficiency audit card and methods for calculating energy savings of 10 August 2012 (Journal of Laws of 2012, item 962),

- Environmental Protection Act of 27 April 2001 (Journal of Laws of 2001, No 62, item 627, as amended),

- Energy Act of 10 April 1997 (Journal of Laws of 1997, No 54, item 348, as amended),

- Construction Act of 7 July 1994 (Journal of Laws of 1994, No 89, item 414, as amended),

- Regulation of the Minister of Transport, Construction and Maritime Economy amending the ordinance on the detailed scope and form of a construction project of 21 June 2013 (Journal of Laws of 2013, item 762),

- Regulation of the Minister of Transport, Construction and Maritime Economy amending the ordinance on technical conditions that must be fulfilled by buildings and their location of 5 July 2013 (Journal of Laws of 2013, item 926),

- Act on promotion of the thermal upgrading and renovation of 21 November 2008 
(Journal of Laws of 2008, No. 223, item 1459, as amended),

- Act on renewable energy sources of 20 February 2015 (Journal of Laws of 2015, item 478 , as amended).

Act on the energy performance of buildings of 29 August 2014 (Journal of Laws of 2014, item 1200 as amended), including executive regulations to the Act, implements Directive 2010/31/EU of the European Parliament and of the Council of 19 May 2010 on the energy performance of buildings (recast) (Official Journal of the European Union No L 153 of 18 June 2010) to Polish law. Among others, Construction Act of 7 July 1994 (Journal of Laws of 1994, No 89, item 414, as amended) was simultaneously changed on the basis of Act on the energy performance of buildings of 29 August 2014 (Journal of Laws of 2014, item 1200 as amended). Introduced legal regulations, in order to achieve the nearly zero-energy construction industry, force the implementation of new design standards, technical and construction requirements for buildings as well as the creation of instruments to support investors planning to build or purchase an energy-efficient building. The validity of the energy performance certificate should be also noted. The legal regulations specify which buildings and premises in what situations must have so-called energy certificate, i.e. a document presenting information on the annual potential demand for energy for central heating, hot water, ventilation and air conditioning, while in the case of a public building also lighting, than comparing this information with the data for the reference building.

Further, Regulation of the Minister of Transport, Construction and Maritime Economy amending the ordinance on the detailed scope and form of a construction project of 21 June 2013 (Journal of Laws of 2013, item 762) and Regulation of the Minister of Economy on the detailed scope and method of preparation of the energy efficiency audit, the model of the energy efficiency audit card and methods for calculating energy savings of 10 August 2012 (Journal of Laws of 2012, item 962) implement Directive 2010/31/EU of the European Parliament and of the Council of 19 May 2010 on the energy performance of buildings (recast) (Official Journal of the European Union No L 153 of 18 June 2010) in Polish legislation. The amendment of 21 June 2013 to Regulation of the Minister of Transport, Construction and Maritime Economy on the detailed scope and form of a construction project of 24 April 2012 (Journal of Laws of 2012, item 462) strengthens the building obligation contained in Section 11(2) point 12 in the scope of analysing the possibilities of rational use of highly effective alternative energy and heat supply systems, as long as there are technical, environmental and economic capabilities available. Currently, the above applies to all buildings regardless of the size of their usable area. 'Highly effective alternative energy and heat supply systems' should be understood as decentralised energy supply systems based on energy from renewable sources, cogeneration, district or block heating or cooling, in particular when it is based completely or partly on energy from renewable sources (within the meaning of Energy Act of 10 April 1997 (Journal of Laws of 1997, No 54, item 348, as amended)) and heat pumps. Moreover, the amendment to Regulation of Minster of Infrastructure on technical conditions that must be fulfilled by buildings and their location of 12 April 2002 (Journal of Laws of 2002, No 75, item 690 as amended), from 1 January 2014, introduces the obligation that buildings must simultaneously meet the requirements regarding the permissible value of the EP indicator (annual demand for non-renewable primary energy) and the minimum thermal insulation of building envelope (walls, floors, roofs, ceilings, windows and doors) and pipes (central heating and hot water installations). By the end of December 2013, it was enough to meet only one of these two requirements. This is a serious challenge for designers, because the value of the EP indicator for a particular building is determined by the combination of many factors, such as: thermal insulation, ventilation method, type 
of fuel for heating the building and even its location. The Regulation defines separate requirements for rebuilt buildings.

Act on promotion of the thermal upgrading and renovation of 21 November 2008 (Journal of Laws of 2008, No. 223, item 1459, as amended), including executive regulations to the Act, makes it possible to increase the energy efficiency of existing buildings. It is one of the best executed legal acts in the construction sector. Most of old buildings do not meet current building requirements, including energy certification. Hence, the support for property owners and managers with financial resources from the Thermal Upgrading and Renovation Fund allows to carry out thermal upgrading and renovation projects to increase energy efficiency of buildings.

Act on renewable energy sources of 20 February 2015 (Journal of Laws of 2015, item 478, as amended) implements Directive 2009/28/EC of the European Parliament and of the Council of 23 April 2009 on the promotion of the use of energy from renewable sources (Official Journal of the European Union No L 140 of 05 June 2009) and Directive 2012/27/EU of the European Parliament and of the Council of 25 October 2012 on energy efficiency (Official Journal of the European Union No L 315 of 14 October 2012) in Polish law. The Act is a complementary legal act to Act on the energy performance of buildings of 29 August 2014 (Journal of Laws of 2014, item 1200 as amended), because it creates attractive legal basis of the implementation of renewable energy installations in the construction industry for investors.

\section{Economic instruments supporting the use of renewable energy sources in the construction industry}

Legal and administrative regulations governing energy efficiency issues in the construction sector in Poland are supported by financial instruments. Historically, the leading supporting programmes for the development of buildings with low energy consumption include:

- 'Improving energy efficiency. Part 2: subsidised loans for building energy-efficient houses', Priority Programme of the National Fund for Environmental Protection and Water Management,

- 'LEMUR - Energy-efficient public buildings', Priority Programme of the National Fund for Environmental Protection and Water Management,

- 'Support for distributed, renewable energy sources. Part 2) PROSUMENT: co-financing the purchase and installation of micro-installations of renewable energy sources', Priority Programme of the National Fund for Environmental Protection and Water Management,

- 'BOCIAN - Distributed, renewable energy sources', Priority Programme of the National Fund for Environmental Protection and Water Management,

- 'KAWKA - Elimination of low emission supporting the increase of energy efficiency and development of distributed, renewable energy sources', Priority Programme of the National Fund for Environmental Protection and Water Management,

- 'Investments in energy efficiency in small and medium-sized enterprises', Priority Programme of the National Fund for Environmental Protection and Water Management,

- 'Green investment system. Energy management in public buildings', Priority Programme of the National Fund for Environmental Protection and Water Management,

- Priority Programmes of Voivodeship Funds for Environmental Protection and Water Management,

- 'PL04: Saving energy and promoting renewable energy sources', Priority Programme of the Norwegian Financial Mechanism and the European Economic Area Financial Mechanism, 
- Swiss-Polish Cooperation Programme. Objective 2: 'Increasing energy efficiency and reducing emission, in particular greenhouse gases and dangerous substances',

- Operational Programme Infrastructure and Environment. Priority Axis I. Investment priority 4.III. 'Supporting energy efficiency, smart energy management and the use of renewable energy sources in public infrastructure, including public buildings and the residential sector',

- Regional Operational Programmes (ROP),

- Thermal Upgrading and Renovation Fund,

- Public Private Partnership (PPP),

- funding programmes in commercial banking.

The basic financial instrument directly supporting energy-efficient construction in Poland is the Priority Programme of the National Fund for Environmental Protection and Water Management entitled 'Improving energy efficiency. Part 2: subsidised loans for building energy-efficient houses', purpose of which is to save energy and reduce or avoid carbon dioxide emissions by co-financing projects that improve the efficiency of energy use in the newly built residential buildings. The programme with a budget of PLN 300 million is implemented in the period 2013-2022 [6]. The amount of contribution depends on the value of the annual unit energy demand indicator for heating and ventilation (EUco), calculated in accordance with the Regulation [1] and is as follows:

- in case of single-family houses:

a) NF40 standard - EUco $\leq 40 \mathrm{kWh} /\left(\mathrm{m}^{2 *}\right.$ year $)$ - PLN 30,000.00 gross grant;

b) NF15 standard - EUco $\leq 15 \mathrm{kWh} /\left(\mathrm{m}^{2 *}\right.$ year $)$ - PLN 50,000.00 gross grant;

- in case of residential units in multi-family houses:

a) NF40 standard - EUco $\leq 40 \mathrm{kWh} /\left(\mathrm{m}^{2 *}\right.$ year $)$ - PLN 11,000.00 gross grant;

b) NF15 standard - EUco $\leq 15 \mathrm{kWh} /\left(\mathrm{m}^{2 *}\right.$ year $)$ - PLN 16,000.00 gross grant.

Priority Programme of the National Fund for Environmental Protection and Water Management entitled 'Support for distributed, renewable energy sources. Part 2) PROSUMENT - co-financing the purchase and installation of micro-installations of renewable energy sources' is one of financial instruments indirectly supporting energyefficient construction in Poland. The programme with a budget of PLN 800 million, implemented in the period 2014-2022, is addressed to individuals as well as homeowner associations and housing cooperatives for co-financing the purchase and assembly of small installations or micro-installations of renewable energy sources for the production of electricity or heat and electricity for the needs of single-family and multi-family houses. Therefore, installations using: 1) biomass heat sources, heat pumps and solar collectors with installed thermal power up to $300 \mathrm{kWt}$, and 2) photovoltaic systems, small wind farms as well as combined heat and power (including micro-biogas plants) with installed power of up to $40 \mathrm{kWe}$, are financed. A loan or a soft loan, including the subsidy, may be up to $100 \%$ of the eligible costs of the installation, with the subsidy being fixed at $20 \%$ or $40 \%$ of the co-financing ( $15 \%$ or $30 \%$ after 2015$)$. Depending on the type of beneficiary and the project, the maximum amount of eligible costs is from PLN 100,000.00 to PLN $450,000.00$ and the loan or soft loan interest rate is set at $1.00 \%$ with a maximum funding period of 15 years [6].

\section{Conclusions}

For the construction sector in Poland, the most important consequence of the existing legal regulations is that by 31 December 2020, all new buildings must be nearly zero-energy buildings and after 31 December 2018, new buildings occupied and owned by public authorities must be nearly zero-energy buildings. These legal requirements resulted in the adoption of the national plan aimed at increasing the number of buildings with low energy 
consumption by the Council of Ministers [7] in Poland. The plan is supported by existing legal bases regulating the use of renewable energy sources in the construction industry.

\section{References}

1. Regulation of the Minister of Infrastructure and Development on the methodology for determining the energy performance of a building or part of a building and energy performance certificates of 27 February 2015 (Journal of Laws of 2015, item 376)

2. A. Kaniszewska, Introduction to energy-efficient and passive construction. http://www.chronmyklimat.pl/projekty/energooszczędne (2013)

3. Information on legal acts of the European Union http://www.europa.eu (access: 29.12.2017)

4. Information on legal acts of the European Union http://buildingsplatform.org (access: 29.12.2017)

5. Data on Polish legal acts http://www.sejm.gov.pl (access: 29.12.2017)

6. Information on the National Fund for Environmental Protection and Water Management (NFEP\&WM) http://www.nfosigw.gov.pl (access: 29.12.2017)

7. Resolution of the Council of Ministers of 22 June 2015 on adoption of 'the National Plan aimed at increasing the number of buildings with low energy consumption' 